\title{
Synthesis and Characterization of Methanesulfonate and Ethanesulfonate Intercalated Lithium Aluminum LDHs
}

\author{
Anton Niksch, Herbert Pöllmann \\ Mineralogy/Geochemistry, Institute for Geosciences and Geography, University of Halle, Halle, Germany \\ Email: herbert.poellmann@geo.uni-halle.de
}

How to cite this paper: Niksch, A. and Pöllmann, H. (2021) Synthesis and Characterization of Methanesulfonate and Ethanesulfonate Intercalated Lithium Aluminum LDHs. Natural Resources, 12, 59-71. https://doi.org/10.4236/nr.2021.123006

Received: February 3, 2021

Accepted: March 20, 2021

Published: March 23, 2021

Copyright (C) 2021 by author(s) and Scientific Research Publishing Inc. This work is licensed under the Creative Commons Attribution International License (CC BY 4.0).

http://creativecommons.org/licenses/by/4.0/

\begin{abstract}
LDH-phases become increasingly interesting due to their broad ability to be able to incorporate many different cations and anions. The intercalation of methanesulfonate and ethanesulfonate into a $\mathrm{Li}-\mathrm{LDH}$ as well as the behavior of the interlayer structure as a function of the temperature is presented. A hexagonal $\mathrm{P}_{3} / \mathrm{m}\left[\mathrm{LiAl}_{2}(\mathrm{OH})_{6}\right]\left[\mathrm{Cl} \cdot 1.5 \mathrm{H}_{2} \mathrm{O}\right]$ ( $\mathrm{Li}-\mathrm{Al}-\mathrm{Cl}$ ) precursor $\mathrm{LDH}$ was synthesized by hydrothermal treating of a $\mathrm{LiCl}$ solution with $\gamma-\mathrm{Al}(\mathrm{OH})_{3}$. This precursor was used to intercalate methanesulfonate $\left(\mathrm{CH}_{3} \mathrm{O}_{3} \mathrm{~S}^{-}\right)$and ethanesulfonate $\left(\mathrm{C}_{2} \mathrm{H}_{5} \mathrm{O}_{3} \mathrm{~S}^{-}\right)$through anion exchange by stirring $\mathrm{Li}-\mathrm{Al}-\mathrm{Cl}$ in a solution of the respective organic $\mathrm{Li}$-salt $\left(90^{\circ} \mathrm{C}, 12 \mathrm{~h}\right)$. X-ray diffraction pattern showed an increase of the interlayer space $c^{\prime}\left(\mathrm{d}_{001}\right)$ of Li-Al-methanesulfonate (Li-Al-MS) with $1.2886 \mathrm{~nm}$ and Li-Al-ethanesulfonate (Li-Al-ES) with 1.3816 $\mathrm{nm}$ compared to the precursor with $0.7630 \mathrm{~nm}$. Further investigations with Fourier-transform infrared spectroscopy and scanning electron microscopy confirmed a complete anion exchange of the organic molecules with the precursor $\mathrm{Cl}^{-}$. Both synthesized $\mathrm{LDH}$ compounds $\left[\mathrm{LiAl}_{2}(\mathrm{OH})_{6}\right] \mathrm{CH}_{3} \mathrm{SO}_{3} \cdot \mathrm{nH}_{2} \mathrm{O}$ (n $=2.24-3.72(\mathrm{Li}-\mathrm{Al}-\mathrm{MS})$ and $\left.\left[\mathrm{LiAl}_{2}(\mathrm{OH})_{6}\right] \mathrm{C}_{2} \mathrm{H}_{5} \mathrm{SO}_{3}\right\} \cdot \mathrm{nH}_{2} \mathrm{O}(\mathrm{n}=1.5)$ ( $\left.\mathrm{Li}-\mathrm{Al}-\mathrm{ES}\right)$ showed a monomolecular interlayer structure with additional interlayer water at room temperature. By increasing the temperature, the interlayer water was removed and the interlayer space $c^{\prime}$ of Li-Al-MS decreased to $0.87735 \mathrm{~nm}$ (at $55^{\circ} \mathrm{C}$ ). Calculations showed that a slight displacement of the organic molecules is necessary to achieve this interlayer space. Different behavior of Li-Al-ES could be observed during thermal treatment. Two phases coexisted at $75^{\circ} \mathrm{C}$ $85^{\circ} \mathrm{C}$, one with a reduced $c^{\prime}\left(0.9015 \mathrm{~nm}, 75^{\circ} \mathrm{C}\right)$ and one with increased $c^{\prime}$ $\left(1.5643 \mathrm{~nm}, 85^{\circ} \mathrm{C}\right)$ compared to the $\mathrm{LDH}$ compound at room temperature. The increase of $c^{\prime}$ is due to the formation of a bimolecular interlayer structure.
\end{abstract}




\section{Keywords}

LDH, Lithium, Aliphatic Sulfonic Acid, X-Ray Powder Diffraction, High

Temperature PXRD, Layered Double Hydroxides, Sulfonate

\section{Introduction}

Layered double hydroxides (LDHs) consist of alternate positively charged mixed metal hydroxide layers and negatively charged interlayer anions and can be normally described by the formula:

$$
\left[\mathrm{M}_{1-\mathrm{x}}^{\mathrm{z}+} \mathrm{M}_{\mathrm{x}}^{3+}(\mathrm{OH})_{2}\right]^{\mathrm{p}+}\left[\left(\mathrm{A}^{\mathrm{n}-}\right)_{\mathrm{p} / \mathrm{n}} \cdot \mathrm{mH}_{2} \mathrm{O}\right]
$$

with $\mathrm{z}=2, \mathrm{M}=$ bi- and trivalent metallic elements, $\mathrm{A}=$ organic or inorganic anions and $\mathrm{m}=$ amount of interlayer $\mathrm{H}_{2} \mathrm{O}$ depending on the relative humidity, hydration level and temperature [1] [2]. The ratio of $\mathrm{M}^{2+}$ to $\mathrm{M}^{3+}$ can be variable [3]. Unlike other LDHs, lithium-containing LDHs are based on the $\mathrm{Al}(\mathrm{OH})_{3}$ structure with a solid cation ratio of 1:2 (Li:Al). The $\mathrm{Al}(\mathrm{OH})_{3}$ structure is built up of double-layered sheets of hexagonally packed $\mathrm{O}$ atoms. Two-thirds of the octahedral holes are occupied by Al Atoms. During a LDH synthesis with LiX (X $=\mathrm{Cl}^{-}, \mathrm{OH}^{-}, \mathrm{NO}_{3}^{-}$, etc.), the remaining third will be occupied by Li Atoms which will lead to the 1:2 ratio [1] [4] [5] [6] [7].

The positive charged main layer must be compensated by a negative charge. This is achieved by the intercalation of anions in the interlayer. These can be both inorganic (e.g. $\mathrm{CO}_{3}^{2-}, \mathrm{Cl}^{-}$) and organic (e.g. $\mathrm{CH}_{3} \mathrm{O}_{3} \mathrm{~S}^{-}$) anions [1] [8] [9] [10] [11]. The interlayer space depends on the type and size respectively chain length and the orientation of the intercalated anion [12]. In the present study, the successful synthesis of $\mathrm{Li}$ - $\mathrm{Al}-\mathrm{LDH}$ with intercalated methanesulfonate $\left(\mathrm{CH}_{3} \mathrm{O}_{3} \mathrm{~S}^{-}\right)$ and ethanesulfonate $\left(\mathrm{C}_{2} \mathrm{H}_{5} \mathrm{O}_{3} \mathrm{~S}^{-}\right)$anions as well as the possible interlayer structure as a function of the temperature is reported. These typical intercalation reactions of LDH-phases and their varying interlayer arrangements are of high interest of layered structures of LDH-type with a main layered metal of ion charge $(+1)$, and the varying compositions and probable applications of these different intercalated LDH phases.

\section{Experimental and Analytical Work}

\subsection{Reagents}

The materials used within this work were $\mathrm{LiCl}$ (Roth, purity $\geq 99 \%), \gamma-\mathrm{Al}(\mathrm{OH})_{3}$ (Merck, purity $\geq 98 \%$ ), $\mathrm{LiOH}$ (AppliChem, purity $\geq 99 \%$ ), $\mathrm{CH}_{4} \mathrm{O}_{3} \mathrm{~S}$ (Lancaster, purity $\geq 98 \%$ ) and $\mathrm{C}_{2} \mathrm{H}_{6} \mathrm{O}_{3} \mathrm{~S}$ (Merck, purity $\geq 98 \%$ ). All chemicals tested by powder X-ray diffraction (PXRD), Fourier-transform infrared spectroscopy (FT-IR) and thermogravimetric analysis (TGA) for purity and loss on ignition (LOI). As methanesulfonic acid and ethanesulfonic acid are in liquid state at room temperature, they were neutralized by $\mathrm{LiOH}$ and transformed into solid 
lithium salts prior to the use in the investigations.

\subsection{Methods}

For PXRD investigations at room temperature, a PANalytical X'PERT ${ }^{3}$ Powder diffractometer with a Pixcel detector and $\mathrm{Cu}$ radiation $(45 \mathrm{kV} / 40 \mathrm{~mA})$ was used. Approximately $1 \mathrm{~g}$ of the respective sample was prepared in a standard sample holder by back loading procedure and recorded from $4^{\circ}-70^{\circ} 2 \theta$ with a step width of $0.013^{\circ} 2 \theta$ and the irradiation time of $20.41 \mathrm{~s}$ per step. High temperature PXRD between $25^{\circ} \mathrm{C}$ and $400^{\circ} \mathrm{C}$ were performed by a PANalytical X'PERT Pro MPD (Cu, $45 \mathrm{kV} / 40 \mathrm{~mA}$ ) with an Anton-Paar high temperature chamber and a X'Celerator detector. The respective sample was prepared on a platinum band and recorded from $2^{\circ}-50^{\circ} 2 \theta$ with a step width of $0.0167^{\circ} 2 \theta$ and an irradiation time of $19.69 \mathrm{~s}$. To record the LOI and determine the type of the vaporized molecule, thermogravimetric analysis with parallel differential scanning calorimetry (TGA/DSC) and coupled mass spectrometer (MS) were performed using a NETZSCH STA449 F3 Jupiter and a NETZSCH QMS 403 D Aëolos. The samples were heated up from $25^{\circ} \mathrm{C}$ to $1000^{\circ} \mathrm{C}$ with a heating rate of $10^{\circ} \mathrm{C} / \mathrm{min}$ within an Argon atmosphere. The chemical composition and the 1:2 ratios between Li and $\mathrm{Al}$ of the main layer were proofed using a Horiba Ultima 2 inductively coupled plasma optical emission spectroscopy (ICP-OES). FT-IR spectra were recorded with a Bruker Tensor II spectrometer $\left(400-4000 \mathrm{~cm}^{-1}\right)$ to verify the complete anion exchange and the intercalation of the organic molecules. Sample pictures were taken by a JOEL 640 scanning electron microscope (SEM). In addition, energy dispersive X-ray spectroscopy (EDX) was performed to detect a possible remainder of precursor $\mathrm{Cl}^{-}$.

\subsection{Synthesis}

Methanesulfonic acid and ethanesulfonic acid were used in the reaction to the newly formed Li-salts by neutralizing the respective acid with $\mathrm{LiOH}$ until a $\mathrm{pH}$ of 7 - 7.5 was reached. The $\mathrm{LDH}\left[\mathrm{LiAL}_{2}(\mathrm{OH})_{6}\right]\left[\mathrm{Cl} \cdot 0.5 \mathrm{H}_{2} \mathrm{O}\right](\mathrm{Li}-\mathrm{Al}-\mathrm{Cl})$ was selected as the precursor due to the easy interchangeability of the $\mathrm{Cl}^{-}$anion [13] and synthesized by a variation of the hydrothermal method [13] [14]. A good crystalline precursor was achieved by adding $1 \mathrm{~g}$ of $\gamma-\mathrm{Al}(\mathrm{OH})_{3}$ to $15 \mathrm{ml}$ of a $\mathrm{LiCl}$ solution with a few drops of 0.5 mole $\mathrm{LiOH}(\mathrm{pH} 8$ - 8.5). The educt ratio of Al:Li was $1: 5$ [15] [16]. The suspension was heated to $100^{\circ} \mathrm{C}$ for 10 hours in an autoclave. After completion of the synthesis the product was filtered, washed with 50 $\mathrm{ml}$ deionized $\mathrm{H}_{2} \mathrm{O}$, dried to a relative humidity $(\mathrm{RH})$ of $35 \%$ and analyzed for purity and amount of crystal water. To exchange $\mathrm{Cl}^{-}$for methanesulfonate or ethanesulfonate, $1 \mathrm{~g}$ of the precursor was added to $25 \mathrm{ml}$ deionized $\mathrm{H}_{2} \mathrm{O}$ and so much of the respective Li-salt was added that a ratio of $\mathrm{Cl}^{-}: \mathrm{X}^{-}\left(\mathrm{X}^{-}=\right.$organic anion) of 1:2 was obtained. The suspensions were heated up to $90^{\circ} \mathrm{C}$ for $12 \mathrm{~h}$ under constant stirring. After completion of the synthesis, the products were filtered, washed with $50 \mathrm{ml}$ deionized $\mathrm{H}_{2} \mathrm{O}$ and dried to $35 \% \mathrm{RH}$. The entire syn- 
thesis processes were performed in a glove box with $\mathrm{N}_{2}$ atmosphere to avoid carbonization.

\section{Results and Discussion}

\subsection{TGA/DSC-MS and ICP-OES Analysis}

Exactly $10 \mathrm{mg}$ of the respective LDH were dissolved in $0.5 \mathrm{ml}$ suprapure $65 \%$ $\mathrm{HNO}_{3}$, diluted with $10 \mathrm{ml}$ deionized $\mathrm{H}_{2} \mathrm{O}$ and measured with ICP-OES. The results showed the expected $\mathrm{Li} / \mathrm{Al}$ ratio of 1:2 and no leftover of $\mathrm{Cl}^{-}$from the precursor. The amount of interlayer water and the amount of the absorbed organic molecule was determined by TGA/DTA-MS with approximately $10 \mathrm{mg}$ of the respective $\mathrm{LDH}$. The mass losses can be divided in three steps for both sulfonate containing LDHs. The interlayer water is removed between $25^{\circ} \mathrm{C}$ and $200^{\circ} \mathrm{C}$ with a total of $2.24 \mathrm{~mol} \mathrm{H}_{2} \mathrm{O}$ for Li-Al-methanesulfonate (Li-Al-MS) and $3.72 \mathrm{~mol}$ $\mathrm{H}_{2} \mathrm{O}$ for Li-Al-ethanesulfonate (Li-Al-ES). The decomposition of the main layer starts at approx. $250^{\circ} \mathrm{C}$ and continues to $295^{\circ} \mathrm{C}$. By removing the $\mathrm{OH}$ groups of the main layer at these elevated temperatures, the crystal structure is destroyed and the LDH compounds become X-ray amorphous. The last large mass loss lies between $400^{\circ} \mathrm{C}$ and $500^{\circ} \mathrm{C}$ and is caused by the breakdown of the organic compounds. Due to the mass spectroscopy, it was possible to differentiate between $\mathrm{H}_{2} \mathrm{O}$ and the organic molecules, which could be measured as fragments in the form of e.g. $\mathrm{CH}^{+}$or $\mathrm{SO}^{2+}$. The chemical composition of both $\mathrm{LDH}$ compounds were therefore calculated (Table 1).

\subsection{FT-IR Spectroscopy}

Li-Al-MS and Li-Al-ES were investigated by FT-IR to proof the intercalation of the organic molecules and the noncarbonization of the relevant synthesis products. Both sulfonate LDHs showed the typical $\mathrm{SO}_{3}^{2-}\left(v 1055 \mathrm{~cm}^{-1}, v_{a s} 1202\right.$ $\left.\mathrm{cm}^{-1}, v_{3} 1242 \mathrm{~cm}^{-1}, v_{a s} 1292 \mathrm{~cm}^{-1}\right), \mathrm{CH}_{3}\left(\delta_{s} 1373 \mathrm{~cm}^{-1}\right), \mathrm{H}_{2} \mathrm{O}\left(v_{2} 1627 \mathrm{~cm}^{-1}\right), \mathrm{OH}$ ( v $\left.3400-3600 \mathrm{~cm}^{-1}\right)$ and $\mathrm{Al}-\mathrm{OH}\left(\delta 752 \mathrm{~cm}^{-1}, \delta 940 \mathrm{~cm}^{-1}\right)$ absorptions. Li-Al-ethanesulfonate showed also the $\mathrm{CH}_{2}\left(\delta_{s} 1417 \mathrm{~cm}^{-1}, v_{a s} 2941 \mathrm{~cm}^{-1}\right)$ absorp-

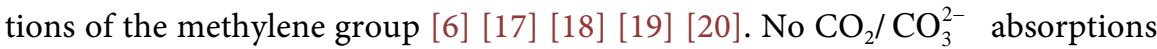
and therefore no carbonization of the compounds could be detected [6] [21].

\subsection{SEM (EDX) Analysis}

The investigated samples were free of $\mathrm{Cl}^{-}$from the initial chemicals which proofed the complete anion exchange between the precursor and the sulfonate anions. Both LDHs formed flat hexagonal crystals with a clearly visible layered structure in crystallographic c-direction (Figure 1). The crystals of Li-Al-MS had an average size of $2-20 \mu \mathrm{m}$ in crystallographic a-direction and $2 \mu \mathrm{m}-10$ $\mu \mathrm{m}$ in crystallographic $c$-direction. In comparison, the crystals of Li-Al-ES were mostly smaller in the a-direction $(1-10 \mu \mathrm{m})$ and showed strongly rounded crystal edges. These small crystals formed hexagonal clusters with layer thicknesses of up to $30 \mu \mathrm{m}$ in $c$-direction. 
Table 1. Calculated and measured compositions (mass \%) of Li-Al-MS and Li-Al-ES (35\% RH).

\begin{tabular}{cccccccc}
\hline & $n_{c}$ & $\mathrm{Li}_{2} \mathrm{O}$ & $\mathrm{Al}_{2} \mathrm{O}_{3}$ & $\mathrm{C}_{\mathrm{n}} \mathrm{H}_{2 \mathrm{n}+1} \mathrm{SO}_{3} \mathrm{H}$ & $\mathrm{H}_{2} \mathrm{O}$ & *interlayer & total \\
\hline calculated & & 5.01 & 34.17 & 32.21 & 28.61 & & 100.00 \\
measured & 1 & 5.07 & 34.07 & 31.24 & 28.56 & $(13.50)$ & 98.94 \\
calculated & & 4.41 & 30.07 & 32.48 & 33.04 & & 100.00 \\
measured & 3 & 4.44 & 30.17 & 31.18 & 33,13 & $(19.78)$ & 98.91 \\
\hline
\end{tabular}

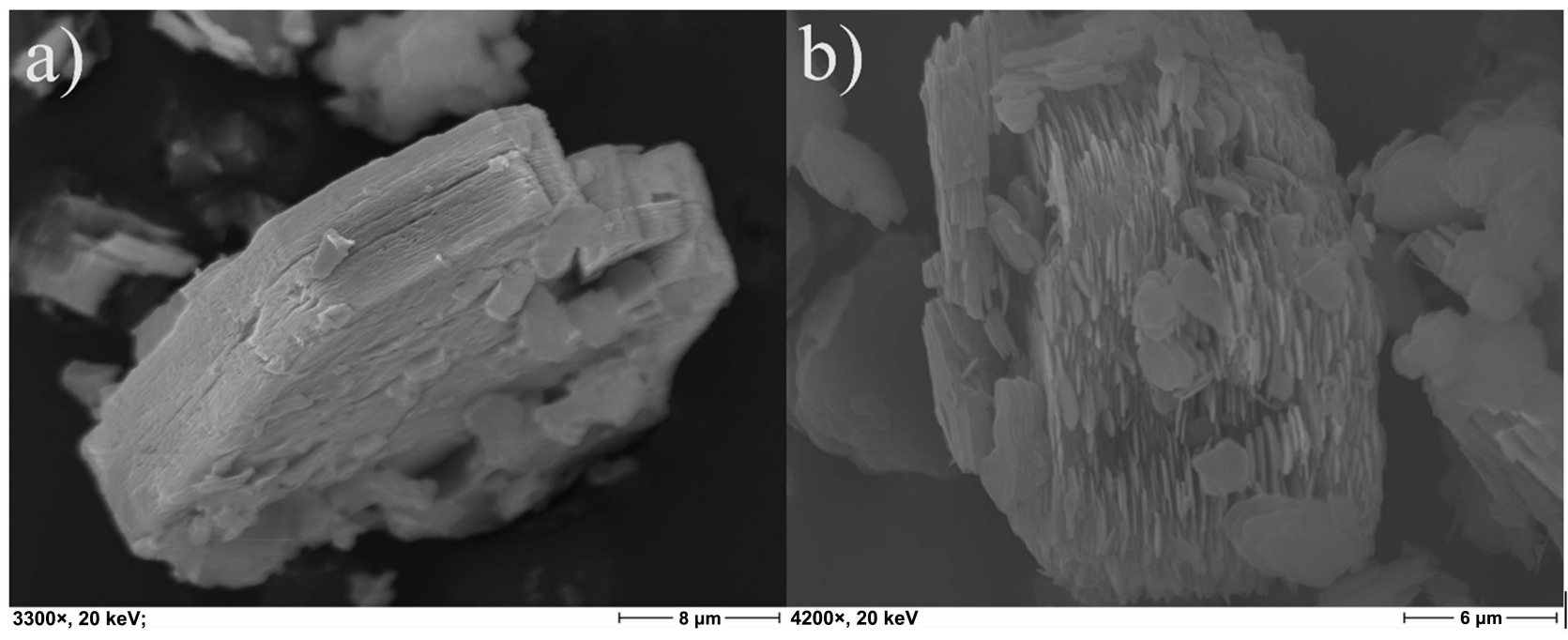

Figure 1. SEM pictures of (a) Li-Al-MS, (b) Li-Al-ES.

\subsection{PXRD Analysis at $25^{\circ} \mathrm{C}$}

The distance between two layers within the LDH structure can be described by the layer distance $c^{\prime}\left(\mathrm{d}_{001}\right)$ and depends on the type, size and inclination angle of the intercalated anion. This inclination angle $\alpha$ can be calculated by using the average increase of $c^{\prime}$ depending on the chain length $(\Delta c)$. Ethanesulfonate molecule is larger and therefore (requires more space in the interlayer, which leads to an increase in the interlayer distance $c$ '. Table 2, Figure 2).

With the calculated $\Delta c^{\prime}=0.0928$ and the given formula $\sin \alpha=\Delta c^{\prime} / 0.127$, the inclination angle of the intercalated molecules is $\alpha=46.95^{\circ}$ (35\% RH) [9].

A Li-Al-LDH layer with intercalated sulfonate anions is normally composed of the positively charged main layer with $0.20 \mathrm{~nm}$ between the $\mathrm{OH}$ groups and $0.29 \mathrm{~nm}$ between the $\mathrm{OH}$ and the $\mathrm{SO}_{3}^{2-}$ group (Figure 3). The terminal methyl group of the organic anions occupies $0.30 \mathrm{~nm}$ and the $\mathrm{H}_{2} \mathrm{O}$ molecules $0.31 \mathrm{~nm}$ of the interlayer space. The occupied space by the remaining part of organic anion can be calculated with the formula: $0.127 \mathrm{~nm} \cdot\left(n_{c}-1\right) \cdot \sin \alpha$ with $n_{c}=$ number of carbon atoms [9]. Based on these data the interlayer space for both LDH compounds could be calculated (Table 3 ).

With only one layer of $\mathrm{H}_{2} \mathrm{O}$ molecules, the differences between the measured and calculated interlayer spaces are too high. By adding mathematically another half layer of $\mathrm{H}_{2} \mathrm{O}$ molecules within the calculation $(0.47 \mathrm{~nm}$ instead of $0.31 \mathrm{~nm})$, 
Table 2. Lattice parameters and amount of interlayer water of Li-Al-Ms and Li-Al-ES.

\begin{tabular}{cccccccc}
\hline$n_{c}$ & $a_{0}[\mathrm{~nm}]$ & $b_{0}[\mathrm{~nm}]$ & $c_{0}[\mathrm{~nm}]$ & $c^{\prime}[\mathrm{nm}]$ & $\beta\left[^{\circ}\right]$ & $\mathrm{H}_{2} \mathrm{O}[\mathrm{mol}]$ & space group \\
\hline 1 & $0.5109(6)$ & & $2.5772(7)$ & $1.2886(3)$ & & 2.24 & $\mathrm{P}_{3} / \mathrm{m}$ \\
2 & $0.5108(8)$ & $0.5165(4)$ & $2.7628(6)$ & $1.3816(3)$ & $92.01(7)$ & 3.72 & $\mathrm{P}_{1} / \mathrm{c}$ \\
\hline
\end{tabular}

Table 3. Calculated and measured interlayer space $c^{\prime}$ of Li-Al-MS and Li-Al-ES with 1 and 1.5 layer of interlayer $\mathrm{H}_{2} \mathrm{O}$ and an inclination angle of $46.95^{\circ}$.

\begin{tabular}{ccccccc}
\hline \multicolumn{4}{c}{1 layer of $\mathrm{H}_{2} \mathrm{O}$ molecules } & \multicolumn{3}{c}{1.5 layer of $\mathrm{H}_{2} \mathrm{O}$} \\
\hline$n_{c}$ & $c_{c}^{\prime}[\mathrm{nm}]$ & $c_{m}^{\prime}[\mathrm{nm}]$ & diff. $[\mathrm{nm}]$ & $c_{c}^{\prime}[\mathrm{nm}]$ & $c_{m}^{\prime}[\mathrm{nm}]$ & diff. $[\mathrm{nm}]$ \\
\hline 1 & 1.100 & 1.2886 & 0.1886 & 1.2600 & 1.2886 & 0.0286 \\
2 & 1.1928 & 1.3816 & 0.1888 & 1.3528 & 1.3816 & 0.0288 \\
\hline
\end{tabular}

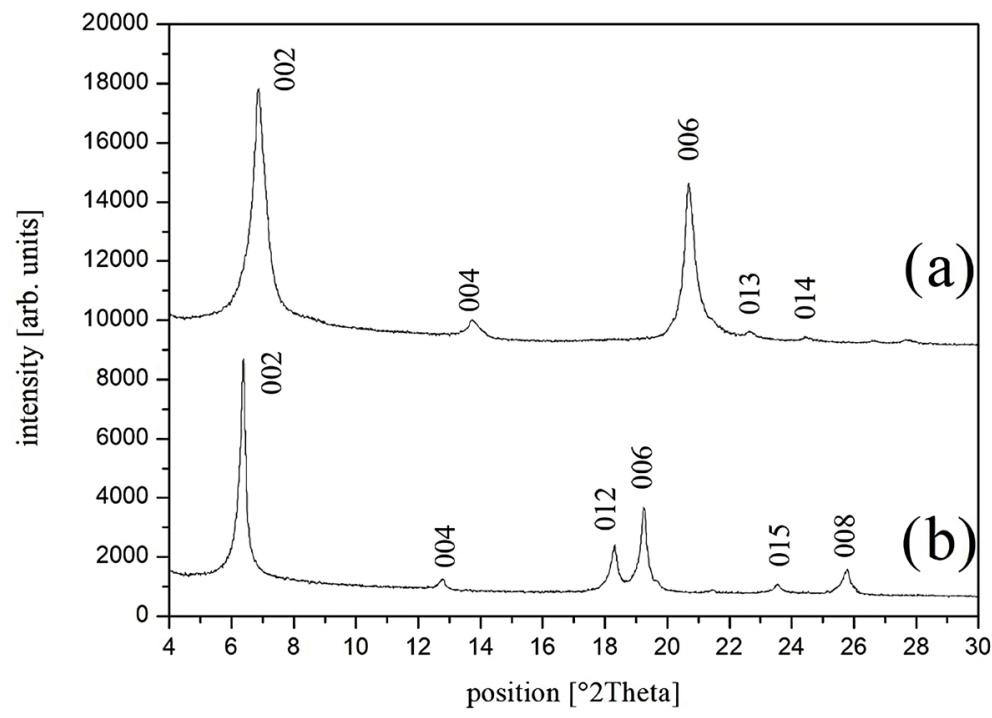

Figure 2. XRD pattern of (a) Li-Al-ES, (b) Li-Al-MS with a shift of Li-Al-ES towards smaller ${ }^{\circ} 2$ theta due to the interlayer anion ethanesulfonate.

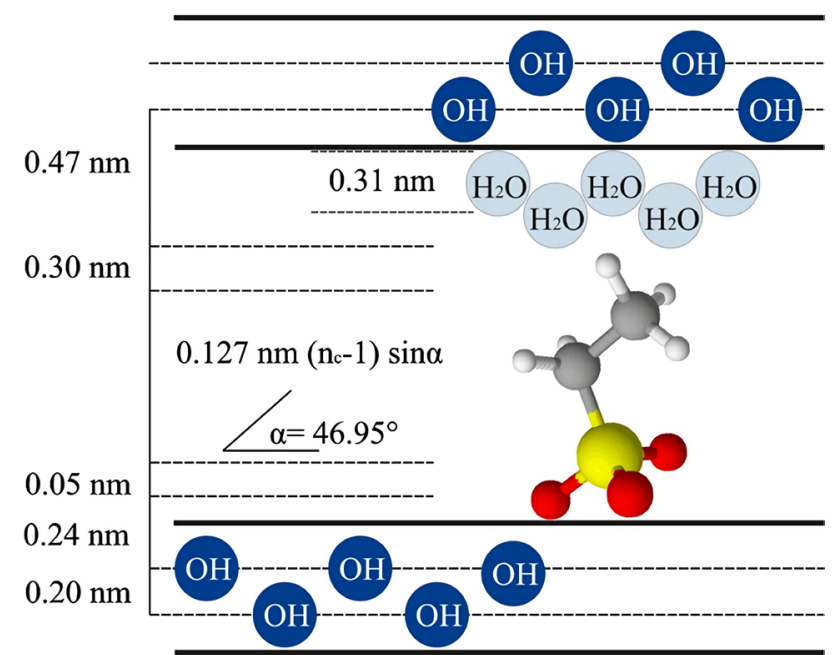

Figure 3. Example for the structure of a Li-Al-ES with an ethanesulfonate anion and 1.5 layers of $\mathrm{H}_{2} \mathrm{O}$ molecules (modified according to [9]). 
the difference could be calculated and adjusted. It can therefore be assumed, that the $\mathrm{H}_{2} \mathrm{O}$ molecules within the interlayer are offset by the half length in $c$-direction to each other (Figure 3).

While Li-Al-MS crystallized in the hexagonal space group $\mathrm{P}_{3} / \mathrm{m}$, the space group of Li-Al-ES could be determined as monoclinic $\mathrm{P} 2_{1} / \mathrm{c}$. The lattice parameters were determined by Pawley fit based on a $2 H \mathrm{Li}$-Al unit cell [15].

\subsection{PXRD Analysis at Higher Temperatures}

The behavior of the LDH phases as a function of temperature was investigated by heating the phases up to $400^{\circ} \mathrm{C}$. Pure $\mathrm{Si}$ was added as standard to the samples to compensate the platinum band expansion and zero shifts.

$\mathrm{Li}$-Al-MS showed a decrease of the lattice parameter $c^{\prime}$ starting at $45^{\circ} \mathrm{C}-55^{\circ} \mathrm{C}$ from the original $1.2286 \mathrm{~nm}$ to $0.9873 \mathrm{~nm}$ followed by a second decrease at $55^{\circ} \mathrm{C}$ $-65^{\circ} \mathrm{C}$ to $0.8773 \mathrm{~nm}$ were the interlayer space remained nearly constant until the decomposition of the main layer at $295^{\circ} \mathrm{C}$ with $c^{\prime}=0.8831 \mathrm{~nm}$ (Figure 4, Table 4). The space group $\mathrm{P}_{3} / \mathrm{m}$ did not change at higher temperatures. Without interlayer $\mathrm{H}_{2} \mathrm{O}$ at temperatures above $200^{\circ} \mathrm{C}$ the calculated interlayer space of $\mathrm{Li}-\mathrm{Al}-\mathrm{MS}$ is $0.79 \mathrm{~nm}$. The difference of $0.0931 \mathrm{~nm}$ between the calculated and the measured $c^{\prime}\left(295^{\circ} \mathrm{C}\right)$ can be explained by a slightly shift of the sulfonate molecules to each other at higher temperatures (Figure 5) [19] [22]. Both phases become X-Ray amorphous at about $300^{\circ} \mathrm{C}$ due to the beginning destruction of main layer.

With a splitting in two different phases at $75^{\circ} \mathrm{C}-85^{\circ} \mathrm{C}$, Li-Al-ES did not show the same behavior. The interlayer spaces $c^{\prime}$ of the two phases are $0.9042 \mathrm{~nm}$ and $1.5643 \mathrm{~nm}$ at $85^{\circ} \mathrm{C}$. Assuming that the sulfonate anions can behave the same way

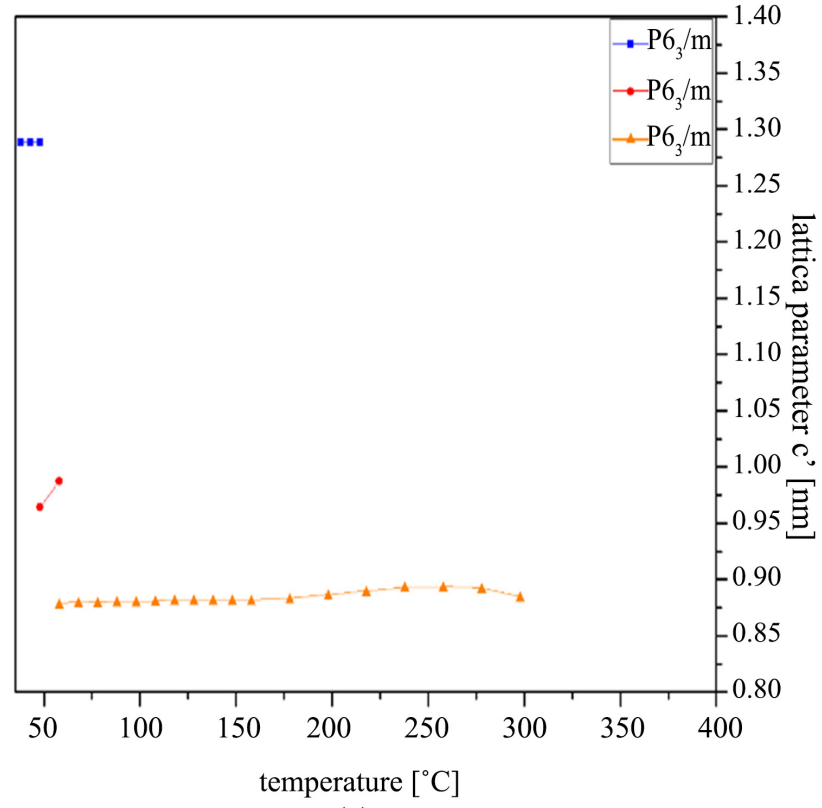

(a)

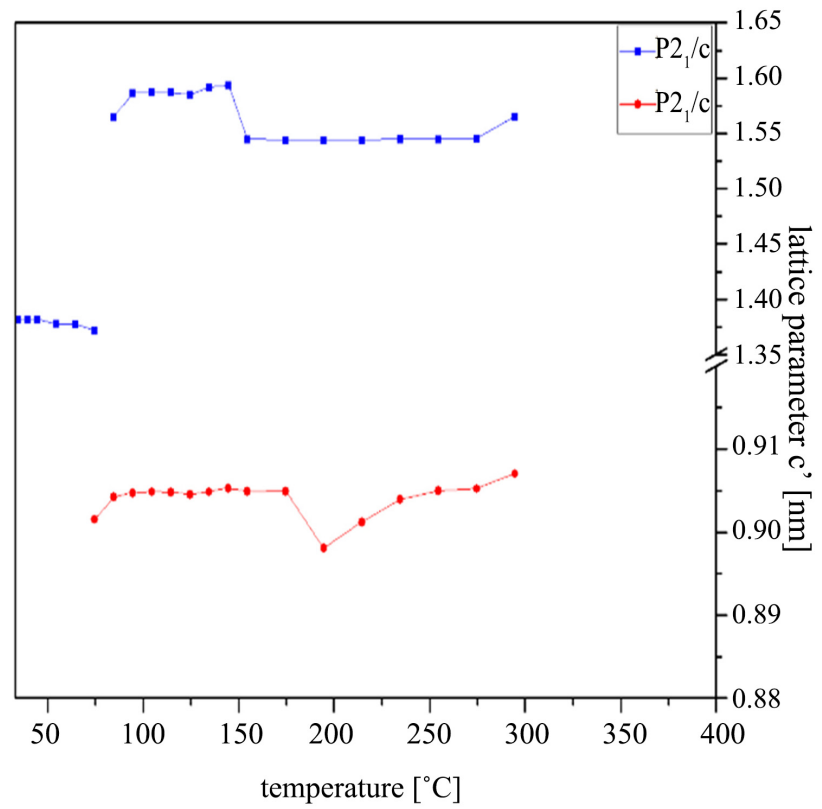

(b)

Figure 4. Shifts of lattice parameters $c^{\prime}$ depending on the temperature of (a) Li-Al-MS and (b) Li-Al-ES. 
Table 4. Lattice distances $c^{\prime}$ of Li-Al-MS and Li-Al-ES depending on the temperature.

\begin{tabular}{|c|c|c|c|c|c|}
\hline \multirow[b]{3}{*}{ temp $\left[{ }^{\circ} \mathrm{C}\right]$} & \multicolumn{5}{|c|}{ lattice distance $c^{\prime}[\mathrm{nm}]$} \\
\hline & \multicolumn{3}{|c|}{ Li-Al-MS } & \multicolumn{2}{|c|}{ Li-Al-ES } \\
\hline & $\mathrm{P}_{3} / \mathrm{m}$ & $\mathrm{P}_{3} / \mathrm{m}$ & $\mathrm{P}_{3} / \mathrm{m}$ & $\mathrm{P} 2{ }_{1} / \mathrm{c}$ & $\mathrm{P} 2{ }_{1} / \mathrm{c}$ \\
\hline 25 & 1.2886 & & & 1.3814 & \\
\hline 26 & 1.2884 & & & 1.3815 & \\
\hline 35 & 1.2884 & & & 1.3815 & \\
\hline 45 & 1.2886 & 0.9643 & & 1.3811 & \\
\hline 55 & & 0.9873 & 0.8773 & 1.3775 & \\
\hline 65 & & & 0.8786 & 1.3774 & \\
\hline 75 & & & 0.8788 & 1.3716 & 0.9015 \\
\hline 85 & & & 0.8791 & 1.5643 & 0.9042 \\
\hline 95 & & & 0.8791 & 1.5866 & 0.9047 \\
\hline 105 & & & 0.8799 & 1.5867 & 0.9048 \\
\hline 115 & & & 0.8809 & 1.5868 & 0.9048 \\
\hline 125 & & & 0.8807 & 1.5847 & 0.9045 \\
\hline 135 & & & 0.8807 & 1.5916 & 0.9049 \\
\hline 145 & & & 0.8806 & 1.5936 & 0.9052 \\
\hline 155 & & & 0.8806 & 1.5443 & 0.9049 \\
\hline 175 & & & 0.8821 & 1.5435 & 0.9049 \\
\hline 195 & & & 0.8853 & 1.5435 & 0.8981 \\
\hline 215 & & & 0.8887 & 1.5437 & 0.9012 \\
\hline 235 & & & 0.8923 & 1.5447 & 0.9039 \\
\hline 255 & & & 0.8923 & 1.5445 & 0.9050 \\
\hline 275 & & & 0.8908 & 1.5448 & 0.9052 \\
\hline 295 & & & 0.8831 & 1.5648 & 0.9070 \\
\hline
\end{tabular}

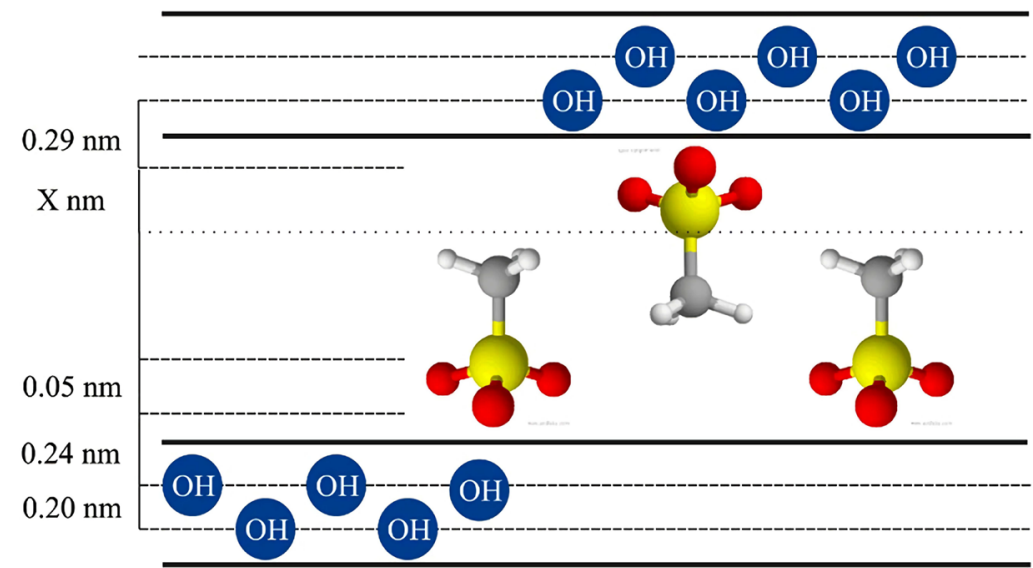

Figure 5. Interlayer structure of Li-Al-MS with a displacement of the methanesulfonate molecules for $x \mathrm{~nm}$ in $c$-direction. 
like aliphatic and aromatic monocarboxylic acids it is possible to form a "double" interlayer structure by placing two sulfonate anions above each other with an inclination angle of $90^{\circ}$ (Figure 6). A doubled interlayer structure with $\alpha=90^{\circ}$ and without interlayer $\mathrm{H}_{2} \mathrm{O}$ (due to the high temperature) has a calculated interlayer space of $1.5840 \mathrm{~nm}$ which fits extremely good with the measured $c^{\prime}$ of the "higher spaced" phase (Table 4). Using only one layer of sulfonate anions in the interlayer structure and $\alpha=90$ for the calculation results in $c_{\text {calc }}^{\prime}=0.9170 \mathrm{~nm}$, which also fits precisely with the measured interlayer spaces (Table 4).

Li-Al-ethanesulfonate hydrate with the lower interlayer phase is therefore a coexisting single layer version of the phase with an "increased interlayer space". No change of the monoclinic space group $\mathrm{P} 2_{1} / \mathrm{c}$ during the heating process could be found.

\subsection{Infrared Spectroscopy}

Li-Al-LDHs with intercalated methanesulfonate (Figure 7) and ethanesulfonate (Figure 8) were also investigated by IR-spectroscopy and their spectra and interpretations (Table 5 and Table 6) are reported.

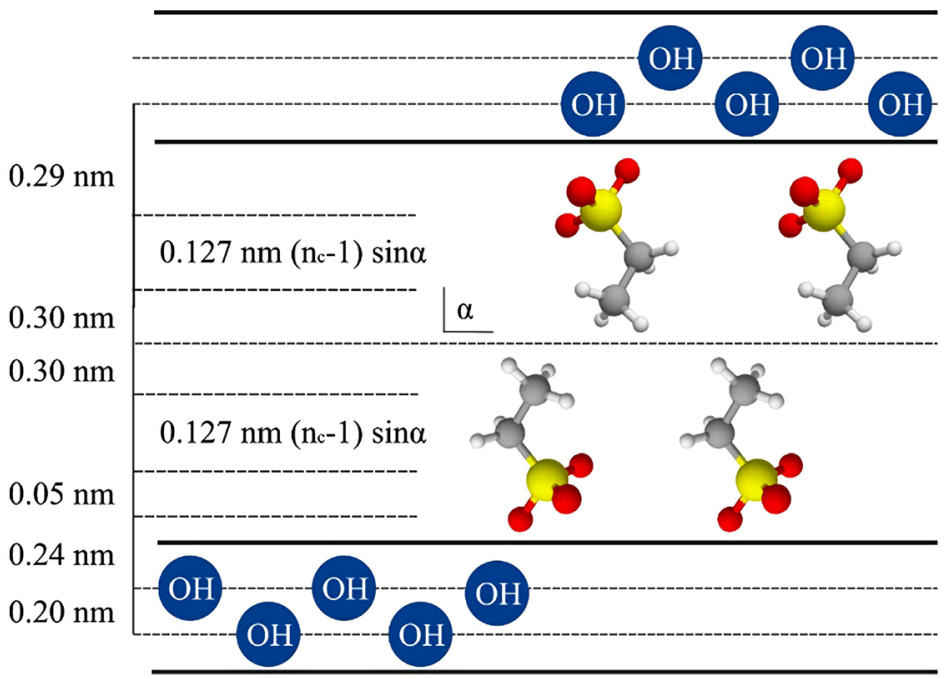

Figure 6. Interlayer structure of Li-Al-ES with a double layer of the ethanesulfonate molecules and an inclination angle of $90^{\circ}$.

Table 5. IR spectroscopic data of $\left[\mathrm{LiAl}_{2}(\mathrm{OH})_{6}\right] \mathrm{X}\left\{\mathrm{X}=\mathrm{CH}_{3} \mathrm{SO}_{3}\right\} \cdot \mathrm{nH}_{2} \mathrm{O}$.

\begin{tabular}{ccc}
\hline vibration $\mathrm{cm}^{-1}$ & & type of vibration \\
\hline $3600-3400$ & $v(\mathrm{OH})$ & $(\mathrm{OH})$-valence vibration-main layer \\
2943 & $v_{1}, v_{3}\left(\mathrm{H}_{2} \mathrm{O}\right)$ & $(\mathrm{H}-\mathrm{O}-\mathrm{H})$-valence vibration-interlayer water \\
1630 & $v_{a s}\left(\mathrm{CH}_{2}\right)$ & asym. $(\mathrm{C}-\mathrm{H})$-valence vibration of $\mathrm{CH}_{2}$-group \\
1417 & $v_{2}\left(\mathrm{H}_{2} \mathrm{O}\right)$ & $(\mathrm{H}-\mathrm{O}-\mathrm{H})$-valence vibration-inter layer water \\
1373 & $\delta_{s}\left(\mathrm{CH}_{2}\right)$ & sym. $(\mathrm{C}-\mathrm{H})$-deformation vibration of $\mathrm{CH}_{2}$-group \\
1292 & $\delta_{s}\left(\mathrm{CH}_{3}\right)$ & sym. $(\mathrm{C}-\mathrm{H})$-deformation vibration of $\mathrm{CH}_{3}$-group \\
& $v_{a s}\left(\mathrm{SO}_{3}^{2-}\right)$ & asym. $\left(\mathrm{SO}_{3}^{2-}\right)$-valence vibration \\
\hline
\end{tabular}




\section{Continued}

\begin{tabular}{ccc}
\hline 1242 & $v_{3}\left(\mathrm{SO}_{3}^{2-}\right)$ & $\left(\mathrm{SO}_{3}^{2-}\right)$-valence vibration \\
1202 & $v_{a s}\left(\mathrm{SO}_{3}^{2-}\right)$ & asym. $\left(\mathrm{SO}_{3}^{2-}\right)$-valence vibration \\
1055 & $v\left(\mathrm{SO}_{3}^{2-}\right)$ & $\left(\mathrm{SO}_{3}^{2-}\right)$-valence vibration \\
1001 & $\delta_{\text {in-pl. }}(\mathrm{CH})$ & $(\mathrm{C}-\mathrm{H})$-deformation vibration in plane \\
934 & $\delta \mathrm{Al}-\mathrm{OH}$ & $(\mathrm{Al}-\mathrm{OH})$-deformation vibration \\
759 & $\delta \mathrm{Al}-\mathrm{OH}$ & $(\mathrm{Al}-\mathrm{OH})-$ deformation vibration \\
535 & $\left(\mathrm{AlO}_{6}\right)$ & $(\mathrm{AlIV}-\mathrm{O})$-vibration \\
460 & $\mathrm{LiO}$ & $(\mathrm{Li}-\mathrm{O})$-vibration \\
\hline
\end{tabular}

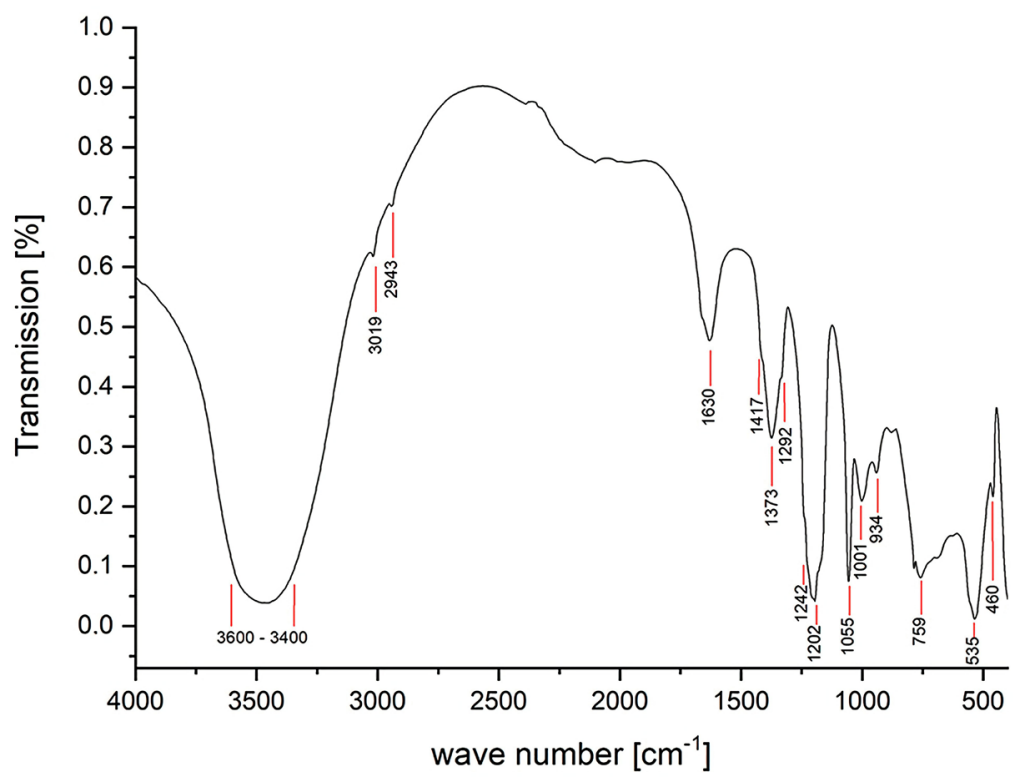

Figure 7. IR spectroscopy of $\left[\mathrm{LiAl}_{2}(\mathrm{OH})_{6}\right] \mathrm{X}\left\{\mathrm{X}=\mathrm{CH}_{3} \mathrm{SO}_{3}\right\} \cdot \mathrm{nH}_{2} \mathrm{O}$.

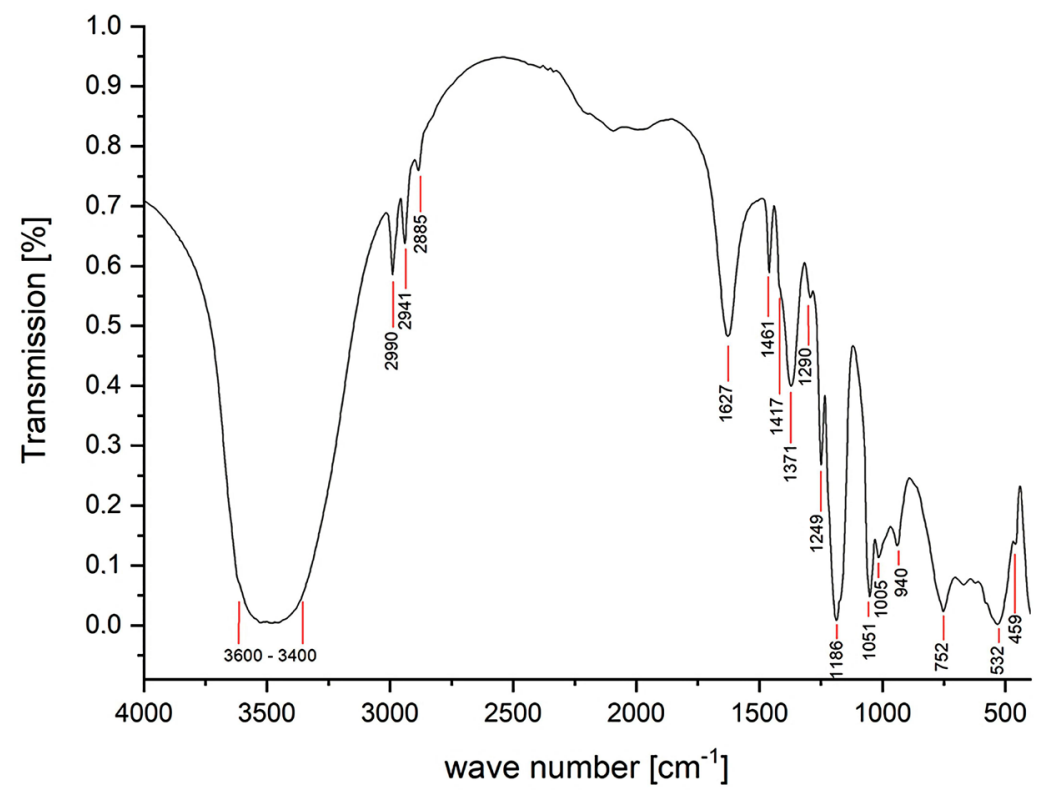

Figure 8. IR spectroscopy of $\left[\mathrm{LiAl}_{2}(\mathrm{OH})_{6}\right] \mathrm{X}\left\{\mathrm{X}=\mathrm{C}_{2} \mathrm{H}_{5} \mathrm{SO}_{3}\right\} \cdot \mathrm{nH}_{2} \mathrm{O}$. 
Table 6. IR spectroscopic data of $\left[\mathrm{LiAl}_{2}(\mathrm{OH})_{6}\right] \mathrm{X}\left\{\mathrm{X}=\mathrm{C}_{2} \mathrm{H}_{5} \mathrm{SO}_{3}\right\} \cdot \mathrm{nH}_{2} \mathrm{O}$.

\begin{tabular}{|c|c|c|}
\hline vibration $\mathrm{cm}^{-1}$ & & Type vibration \\
\hline \multirow{2}{*}{$3600-3400$} & $v(\mathrm{OH})$ & $(\mathrm{OH})$ - valence vibration-main layer \\
\hline & $v_{1}, v_{3}\left(\mathrm{H}_{2} \mathrm{O}\right)$ & $(\mathrm{H}-\mathrm{O}-\mathrm{H})$ - valence vibration-interlayer water \\
\hline 2990 & $v_{a s}\left(\mathrm{CH}_{3}\right)$ & asym. $(\mathrm{C}-\mathrm{H})$ - valence vibration of $\mathrm{CH}_{3}$-group \\
\hline 2941 & $v_{a s}\left(\mathrm{CH}_{2}\right)$ & asym. $(\mathrm{C}-\mathrm{H})$ - valence vibration of $\mathrm{CH}_{2}$-group \\
\hline 2885 & $v_{s}\left(\mathrm{CH}_{2}\right)$ & sym. $(\mathrm{C}-\mathrm{H})$-valence vibration of $\mathrm{CH}_{2}$-group \\
\hline 1627 & $v_{2}\left(\mathrm{H}_{2} \mathrm{O}\right)$ & $(\mathrm{H}-\mathrm{O}-\mathrm{H})$ - valence vibration-interlayer water \\
\hline 1461 & $\delta_{a s}\left(\mathrm{CH}_{3}\right)$ & asym. $(\mathrm{C}-\mathrm{H})$-deformation vibration of $\mathrm{CH}_{3}$-group \\
\hline 1417 & $\delta_{s}\left(\mathrm{CH}_{2}\right)$ & sym. $(\mathrm{C}-\mathrm{H})$-deformation vibration of $\mathrm{CH}_{2}$-group \\
\hline 1371 & $\delta_{s}\left(\mathrm{CH}_{3}\right)$ & sym. $(\mathrm{C}-\mathrm{H})$-deformation vibration of $\mathrm{CH}_{3}$-group \\
\hline 1290 & $v_{a s}\left(\mathrm{SO}_{3}^{2-}\right)$ & asym. $\left(\mathrm{SO}_{3}^{2-}\right)$-valence vibration \\
\hline 1249 & $v_{3}\left(\mathrm{SO}_{3}^{2-}\right)$ & $\left(\mathrm{SO}_{3}^{2-}\right)$-valence vibration \\
\hline 1186 & $v\left(\mathrm{SO}_{2}\right)$ & $\left(\mathrm{SO}_{3}^{2-}\right)$-valence vibration \\
\hline 1051 & $v\left(\mathrm{SO}_{3}^{2-}\right)$ & $\left(\mathrm{SO}_{3}^{2-}\right)$-valence vibration \\
\hline 1005 & $\delta_{\text {in-pl. }}(\mathrm{CH})$ & $(\mathrm{C}-\mathrm{H})$ - deformation vibration within plane \\
\hline 940 & $\delta \mathrm{Al}-\mathrm{OH}$ & $(\mathrm{Al}-\mathrm{OH})$-deformation vibration \\
\hline 752 & $\delta \mathrm{Al}-\mathrm{OH}$ & $(\mathrm{Al}-\mathrm{OH})$-deformation vibration \\
\hline 532 & $\left(\mathrm{AlO}_{6}\right)$ & (Al-O)-vibration \\
\hline 459 & $\mathrm{LiO}$ & (Li-O)-vibration \\
\hline
\end{tabular}

The different vibrations of $\left[\mathrm{LiAl}_{2}(\mathrm{OH})_{6}\right] \mathrm{X}\left\{\mathrm{X}=\mathrm{CH}_{3} \mathrm{SO}_{3}\right\} \cdot \mathrm{nH}_{2} \mathrm{O}$ were interpreted in Table 5.

The different vibrations of $\left[\mathrm{LiAl}_{2}(\mathrm{OH})_{6}\right] \mathrm{X}\left\{\mathrm{X}=\mathrm{C}_{2} \mathrm{H}_{5} \mathrm{SO}_{3}\right\} \cdot \mathrm{nH}_{2} \mathrm{O}$ were interpreted in Table 6.

\section{Conclusions}

The synthesis of crystalline and pure Li-Al-LDHs with intercalated methanesulfonate and ethanesulfonate by the anion exchange method using a $\mathrm{Li}-\mathrm{Al}-\mathrm{Cl}$ precursor is easily possible.

The following compositions were determined:

1) Li-Al-MS (Methylsulfonate)

$$
\left[\mathrm{LiAl}_{2}(\mathrm{OH})_{6}\right] \mathrm{X}\left\{\mathrm{X}=\mathrm{CH}_{3} \mathrm{SO}_{3}\right\} \cdot n \mathrm{nH}_{2} \mathrm{O}(\mathrm{n}=2.24-3.72)
$$

2) Li-Al-ES (Ethylsulfonate)

$$
\left[\mathrm{LiAl}_{2}(\mathrm{OH})_{6}\right] \mathrm{X}\left\{\mathrm{X}=\mathrm{C}_{2} \mathrm{H}_{5} \mathrm{SO}_{3}\right\} \cdot n \mathrm{nH}_{2} \mathrm{O}(\mathrm{n}=1.5)
$$

Calculations showed that the organic molecules were intercalated not in a flat arrangement, but with an inclination angle of $\alpha=46.95^{\circ}$ at $25^{\circ} \mathrm{C}$. By increasing the temperature, the inclination angle changed to $90^{\circ}$. Li-Al-ES also showed a complete change of a part of the interlayer structure by stacking two organic molecules on top of each other (bimolecular) at higher temperatures. The other 
part remained in an unstacked single layer structure (monomolecular). The coexistence of both phases could be explained by a new formed superstructure arrangement. While Li-Al-MS remains in a monomolecular structure, the displacement of the organic molecules may indicate an incomplete formation of a bimolecular structure. By changing the environmental temperature, the interlayer structure and distance can be controlled.

\section{Acknowledgements}

The work was carried out at the University of Halle/Saale. The great help of people in the laboratory is gratefully acknowledged.

\section{Conflicts of Interest}

The authors declare no conflicts of interest regarding the publication of this paper.

\section{References}

[1] Williams, G.R., Dunbar, T.G., Beer, A.J., et al. (2006) Intercalation Chemistry of the Novel Layered Double Hydroxides $\left[\mathrm{MAl}_{4}(\mathrm{OH})_{12}\right]\left(\mathrm{NO}_{3}\right)_{2} \cdot \mathrm{yH}_{2} \mathrm{O}(\mathrm{M}=\mathrm{Zn}, \mathrm{Cu}, \mathrm{Ni}$ and Co). 1: New Organic Intercalates and Reaction Mechanisms. Journal of Materials Chemistry, 16, 1222-1230. https://doi.org/10.1039/b514874j

[2] Hernandez-Moreno, M., Ulibarri, M.A., Rendon, J.L. and Serna, C.J. (1985) IR Characteristics of Hydrotalcite-Like Compounds. Physics and Chemistry of Minerals, 12, 34-38.

[3] Khan, A.I. and O’Hare, D. (2002) Intercalation Chemistry of Layered Double Hydroxides: Recent Developments and Applications. Journal of Materials Chemistry, 12, 3191-3198. https://doi.org/10.1039/B204076J

[4] Tarasov, K.A., .Isupov, V.P., Chupakhina, L.E. and O’Hare, D. (2004) A time Resolved, In-Situ X-Ray Diffraction Study of the De-Intercalation of Anions and Lithium Cations from $\left[\mathrm{LiAl}_{2}(\mathrm{OH})_{6}\right]_{\mathrm{n}} \mathrm{X} \cdot \mathrm{qH}_{2} \mathrm{O}\left(\mathrm{X}=\mathrm{Cl}^{-}, \mathrm{Br}^{-}, \mathrm{NO}_{3}^{-}, \mathrm{SO}_{4}^{2-}\right)$. Journal of Materials Chemistry, 14, 1443-1447. https://doi.org/10.1039/B314473A

[5] Millange, F., Walton, R.I., Lei, L. and O'Hare, D. (2000) Efficient Separation of Terephthalate and Phthalate Anions by Selective Ion-Exchange Intercalation in the Layered Double Hydroxide $\mathrm{Ca}_{2} \mathrm{Al}(\mathrm{OH})_{6} \cdot \mathrm{NO}_{3} \cdot 2 \mathrm{H}_{2} \mathrm{O}$. Chemistry of Materials, 12 , 1990-1994. https://doi.org/10.1021/cm0002057

[6] Isupov, V.P., Chupakhina, L.E., Mitrofanova, R.P. and Tarasov, K.A. (2000) Synthesis, Structure, Properties, and Application of Aluminium Hydroxide Intercalation Compounds. Chemistry for Sustainable Development, 8, 121-127.

[7] Williams, G.R., Fogg, A.M., Sloan, J., Taviot-Gueho, C. and O'Hare, D. (2007) Staging during Anion-Exchange Intercalation into $\left[\mathrm{LiAl}_{2}(\mathrm{OH})_{6}\right] \mathrm{Cl} \cdot \mathrm{yH}_{2} \mathrm{O}$ : Structural and Mechanistic Insights. Dalton Transactions, 2017, 3499-3506.

https://doi.org/10.1039/b705753a

[8] Lei, L., Millange, F., Walton, R.I. and O'Hare, D. (2000) Efficient Separation of Pyridinedicarboxylates by Preferential Anion Exchange Intercalation in $\left[\mathrm{LiAl}_{2}(\mathrm{OH})_{6}\right] \mathrm{Cl} \cdot \mathrm{H}_{2} \mathrm{O}$. Journal of Materials Chemistry, 10, 1881-1886. https://doi.org/10.1039/b002719g

[9] Meyn, M. (1991) Doppelhydroxyde und Hydroxidoppelsalze-Synthese, Eigenschaf- 
ten und Anionenaustauschverhalten, Dissertation, Kiel.

[10] Newman, S.P. and Jones, W. (1998) Synthesis, Characterization and Applications of Layered Double Hydroxides Containing Organic Guests. New Journal of Chemistry, 22, 105-115. https://doi.org/10.1039/a708319j

[11] Ragavan, A., Williams, G.R. and O’Hare, D. (2009) A Thermodynamically Stable Layered Double Hydroxide Heterostructure. Journal of Materials Chemistry, 19, 4211-4216. https://doi.org/10.1039/b822390d

[12] Niksch, A. and Pöllmann, H. (2017) Synthesis and Characterization of a $\left[\mathrm{Li}_{0+\mathrm{x}} \mathrm{Mg}_{2-2 \mathrm{x}} \mathrm{Al}_{1+\mathrm{x}}(\mathrm{OH})_{6}\right]\left[\mathrm{Cl} \cdot \mathrm{m} \mathrm{H}_{2} \mathrm{O}\right]$ Solid Solution with $\mathrm{x}=0-1$ at Different Temperatures. Natural Resources, 8, 445-459.

[13] Roy, D.M., Roy, R. and Osborn, E.F. (1953) The System $\mathrm{MgO}-\mathrm{Al}_{2} \mathrm{O}_{3}-\mathrm{H}_{2} \mathrm{O}$ and Influence of Carbonate and Nitrate Ions on the Equilibria. American Journal of Science, 251, 337-361. https://doi.org/10.2475/ajs.251.5.337

[14] Nayak, M., Kutty, T.R.N., Jayaraman, V. and Periaswamy, G. (1997) Preparation of the layered double hydroxide $(\mathrm{LDH}) \mathrm{LiAl}_{2}(\mathrm{OH})_{7} \cdot 2 \mathrm{H}_{2} \mathrm{O}$, by Gel to Crystallite Conversion and a Hydrothermal Method, and Its Conversion to Lithium Aluminates. Journal of Materials Chemistry, 7, 2131-2137. https://doi.org/10.1039/a702065a

[15] Besserguenev, A.V., Fogg, A.M., Francis, R.J., Price, S.J. and O’Hare, D. (1997) Synthesis and Structure of the Gibbsite Intercalation Compounds $\left[\mathrm{LiAl}_{2}(\mathrm{OH})_{6}\right] \mathrm{X}\{\mathrm{X}$ $\left.=\mathrm{Cl}, \mathrm{Br}, \mathrm{NO}_{3}\right\}$ and $\left[\mathrm{LiAl}_{2}(\mathrm{OH})_{6}\right] \mathrm{Cl} \cdot \mathrm{H}_{2} \mathrm{O}$ using Synchrotron X-Ray and Neutron Powder Diffraction. Chemistry of Materials, 9, 241-247. https://doi.org/10.1021/cm960316z

[16] Poellmann, H., Stöber, S. and Stern, E. (2006) Synthesis, Characterization and Reaction Behavior of Lamellar AFm Phases with Aliphatic Sulfonate-Anions. Cement and Concrete Research, 36, 2039-2048. https://doi.org/10.1016/j.cemconres.2006.06.008

[17] Chisem, I.C. and Jones, W. (1994) Ion-Exchange Properties of Lithium Aluminium Layered Double Hydroxides. Journal of Materials Chemistry, 4, 1737-1744. https://doi.org/10.1039/jm9940401737

[18] Guo, S., Li, D., Zhang, W., Pu, M., Evans, D.G. and Duan, X. (2004) Preparation of an Anionic Azo Pigment-Pillared Layered Double Hydroxide and the Thermo- and Photostability of the Resulting Intercalated Material. Journal of Solid State Chemistry, 177, 4597-4606. https://doi.org/10.1016/j.jssc.2004.09.028

[19] Markland, C., Williams, G.R. and O'Hare, D. (2011) The Intercalation of Flavouring Compounds into Layered Double Hydroxides. Journal of Materials Chemistry, 21, 17896-17903. https://doi.org/10.1039/c1jm13375f

[20] Raki, L., Beaudoin, J.J. and Mitchell, L. (2004) Layered Double Hydroxide-Like Materials: Nanocomposites for Use in Concrete. Cement and Concrete Research, 34, 1717-1724. https://doi.org/10.1016/j.cemconres.2004.05.012

[21] Fan, M., Dai, D. and Huang, B. (2012) Fourier Transform Infrared Spectroscopy for Natural Fibres. In: Salih, S., Ed., Fourier Transform-Materials Analysis, IntechOpen, London, United Kingdom. https://doi.org/10.5772/35482

[22] Poeppelmeier, K.R. and Hwu, S.J. (1986) Synthesis of Lithium Dialuminate by Salt Inhibition. Inorganic Chemistry, 26, 3297-3302.https://doi.org/10.1021/ic00267a017 